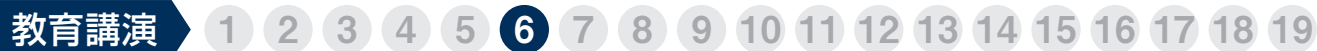

\section{原発性マクログロブリン血症の 診断と治療}

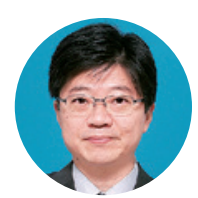

飯田真介

Key words Waldenström's macroglobulinemia (WM), diagnosis, treatment, MYD88, ibrutinib

\section{はじめに}

スウェーデンのJan Gosta Waldenströmは, 1944 年に粘膜出血, リンパ節腫大, 正球性貧 血, 血小板減少, 赤沈六進, 低アルブミン血症, 低フィブリノゲン血症, 骨髄中リンパ系細胞増 加を示す 2 名の患者を報告した。溶骨病変を認 めないことから, 多発性骨髄腫とは異なるこ と, さらに，高ガンマグロブリン血症を呈し血 液粘度が上昇していることも報告した。広義の マクログロブリン血症 (macroglobulinemia) は, 単クローン性IgM（immunoglobulin M）を産生 するリンパ増殖性疾患を示し, 慢性リンパ性白 血病やさまざまなB細胞性リンパ腫も含まれ る. 狭義には, IgM型の意義不明の単クローン 性ガンマグロブリン血症 (monoclonal gammopathy of undetermined significance of the IgM type : IgM MGUS), 〈すぶり型マクログロブリ ン血症 (smoldering Waldenström macroglobulinemia：SWM), 原発性マクログロブリン血症
(Waldenström macroglobulinemia：WM）を指 す $^{1,2)}$.

\section{1. 疾患概念と疫学}

2000年以降, 国際WM作業部会 (International Workshop on WM : IWWM）が隔年で開催され, 診断基準, 効果判定基準, 治療指針が公表され ている. IgM MGUSは前がん病態であり, 血清 $\operatorname{IgM}<3 \mathrm{~g} / \mathrm{dl}$, 骨髄中リンパ形質細胞 $<10 \%$, か つ, 無症状で蔵器障害を認めない. 年 $1.5 \%$ の割 合でWMやアミロイドーシスへ進行する. SWM は血清IgM $\geqq 3 \mathrm{~g} / \mathrm{dl}$, または骨髄中リンパ形質細 胞 $\geqq 10 \%$ であるが, 無症状で藏器障害を認めな い病態を指し，10年間で $68 \%$ がWM, リンパ腫 やアミロイドーシスに進行したことが報告され ている3 . WMは血清IgM濃度や骨髄中リンパ形 質細胞割合にかかわらず, 過粘稠度症候群, 貧 血, B症状, リンパ節腫大, 神経障害やアミロ イドーシス等の臟器障害を認める場合で, 症候

Shinsuke Iida : Department of Hematology and Oncology, Nagoya City University Graduate School of Medical Sciences, Japan. 本講演は, 平成29年 4 月 14 日 (金) 東京都・東京国際フォーラムにて行われた. 
性マクログロブリン血症 (symptomatic WM) と も呼ばれる. World Health Organization（WHO） 分類では, リンパ形質細胞リンパ腫（lymphoplasmacytic lymphoma：LPL）とほぼ同義である が, WMはLPLの中でも骨髄にリンパ形質細胞浸 潤を認め, 単クローン性IgMを産生する病型に 限定して使用される.

米国におけるWMの罹患率は年間 100 万人に 2～3 人という稀な疾患で, 毎年およそ 1,400 人 の患者が新規に診断されている. 発症年齢の中 央值は 64 歳, 男性が $60 \%$ を占め, LPLの 7 割が WMである。我が国においては, 悪性リンパ腫 の0.7\%を占める.また, 欧米のWM患者の $20 \%$ に, 一親等以内にリンパ系腫瘍が認められる. 米国におけるSurveillance, Epidemiology, and End Results（SEER）データベースに登録された WM患者の生存期間中央值は, 1991 2000年 の登録患者で 6 年と報告されているが, 治療法 の進歩により2001～2010年の登録患者では 8 年に延長している. また, 患者年齢を考慮した 相対的生存割合は，5年で $73 \% ， 10$ 年で $57 \%$ である。

\section{2. 分子病態}

2012年にTreonらは, 30名のWM患者検体の 全ゲノムシークエンスを実施し，27名において 染色体3p22.2に位置するMYD88 (myeloid differentiation primary response gene 88) のL265P 体細胞変異が共通して認められることを報告し た4). MYD88は, Toll-like receptor-4 やinterleukin-1 receptorの細胞内シグナルの活性化に関 与するが, L265P変異はIRAK（interleukin-1 receptor-associated kinase) 依存性経路とブルト ン型チロシンリン酸化酵素 (Bruton's tyrosine kinase：BTK）活性化を介してNF-кB（nuclear factor- $\kappa \mathrm{B}$ ) シグナルを恒常的に活性化する. 本 変異はWM患者の 9 割に認め, 非胚細胞中心型 びまん性大細胞型リンパ腫や辺縁層リンパ腫の
20\%程度にも認めるが, 多発性骨髄腫では認め られず, 比較的WMに特異性の高い異常である. また, IgM MGUS患者においても高頻度に認め ることから，一次的異常と考えられている. MYD88以外で変異頻度が高いのはCXCR4 (27\%), ARIAD1A (17\%) である. CXCR4 (CXCchemokine receptor-4) はケモカインCXCL12に 対する膜貫通型受容体蛋白であり, ERK (extracellular signal-regulated kinase) 1/2, p38, SAPK (stress-activated protein kinase)/JNK (c-Jun N-terminal kinase), AKT (protein kinase B), mTOR (mammalian target of rapamycin), BTK 等の細胞内シグナルを活性化する ${ }^{5)}$. WHIM症候 群 (warts, hypogammaglobulinemia, infections, and myelokathexis syndrome) で認められる S338 変異等C末端でのナンセンス変異とフレー ムシフト変異が多い. CXCR4 ${ }^{W H I M}$ 変異は, 興味 深いことにMYD88変異と必ず共存しており, WMに打ける二次的異常と考えられる.

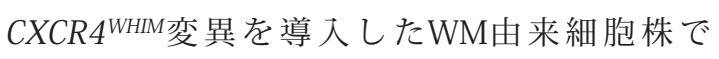
は, 組織浸潤能と増殖能の六進を認め, BTK阻 害薬やmTOR阻害薬に対する耐性も獲得する.

\section{3. 診断}

第2回IWWMによるWMの診断基準を示す（表 1) ${ }^{6)}$. 診断時症候としては, 全身症状（B症状） $23 \%$, 出血 23\%, 神経症状 22\%, 高粘稠度症 候群による視力障害・眩暈・頭痛等の症状 $31 \%$, リンパ節腫大 $25 \%$, 肝腫大 $24 \%$, 脾腫 $19 \%$, 眼底所見の異常 34\%等が多い. 他に, 肺, 腎, 消化管, 皮膚の異常 (Schnitzler症候 群), 骨病変等がある. 欧米では骨病変の合併は $1 \%$ 未満とされているが, 我が国では $37 \%$ との 報告もあり, 病態に民族差がある可能性があ る. 本疾患の特徵であるIgMは五量体を形成し, 過粘稠度症候群（hyperviscosity syndrome）を 引き起こす. 時にIgMが抗myelin associated glycoprotein (MAG) 活性, 抗ganglioside M1 (GM1) 
活性や未梢神経鞘のスルファチド基に対する自 己抗体活性を持ち, 未梢神経障害を呈すること がある.IgMがI型やII型クリオグロブリン活性 を示す場合はRaynaud症状, 紫斑, 寒冷躊麻疹, 関節痛, 腎不全症状を呈し, 寒冷凝集素活性を 持つ場合は網状皮斑, 肢端チアノーゼや溶血性 貧血等を呈する．M蛋白の一部がアミロイド, あるいは非アミロイド蛋白として全身臓器に沈 着することもある. 稀に, 腫瘍細胞が中枢神経 系へ浸潤することがあり, Bing-Neel syndrome （BNS）と呼ばれる。脳脊髄液検査やMRI（mag-

\section{表 1 Waldenström's Macroglobulinemia（WM）の 診断規準（第2回 IWWM）}

(Owen RG, et al : Seminars in Oncol 30 : 110-115, 2003より引用)

・単クローン性IgM血症（IgMの量は問わない）

・形質細胞 (様) 分化を示す小リンパ球の骨髄浸潤

・骨梁間型の骨髄浸潤

- 免疫形質*は， surface lgM+CD5 \pm CD10-CD19+CD20+ CD22+CD23-CD25+CD27+FMC7+CD103-CD138形質細胞分化を示すと，CD138+CD38+CD45-/dimと なる

*免疫形質にはバリエーションがあり，他のリンパ増殖性疾患 を十分に除外する必要がある. 特にCD5陽性例では，慢性リ ンパ性白血病やマントル細胞リンパ腫を除外する. netic resonance imaging) 所見により診断される が, BNSの 36\%はWMの初発症状として認めら れる. BNS患者の初期治療による奏効割合は $70 \%$, 診断後の 5 年生存割合は $71 \%$ と緩徐な経 過を示すことが多い.

WMを診断するうえでは, IgM型M蛋白を産生 し得る他の成熟 $B$ 細胞腫瘍の除外が必要とな る. 特にIgM型多発性骨髄腫, 脾臓原発辺縁層 リンパ腫, マントル細胞リンパ腫, 慢性リンパ 性白血病, 濾胞性リンパ腫等の疾患の鑑別が重 要である.

\section{4. 予後予測因子}

未治療症候性WM患者の予後予測モデルとし ては, International Prognostic Scoring System for WM (ISSWM) が用いられる (図 1) ${ }^{7)}$.

\section{5. 治療}

\section{1）治療開始基準と治療効果判定基準}

前がん病態であるIgM MGUSやSWMは, 注意

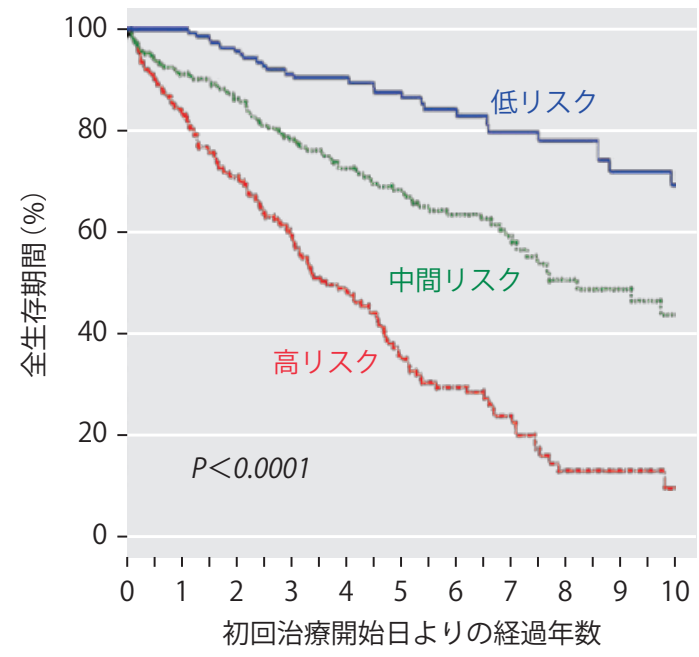

\begin{tabular}{|c|c|c|c|}
\hline \multicolumn{3}{|c|}{ 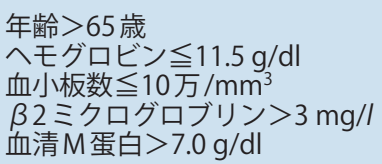 } & \\
\hline Risk category & score & $\begin{array}{l}5-y r \\
\text { OS }\end{array}$ & $\begin{array}{l}\mathrm{mOS} \\
(\mathrm{mo})\end{array}$ \\
\hline $\begin{array}{c}\text { 低リスク } \\
\text { Low }(27 \%)\end{array}$ & 0 or 1 & $87 \%$ & 142.5 \\
\hline $\begin{array}{c}\text { 中間リスク } \\
\text { Intermediate } \\
(38 \%)\end{array}$ & $\begin{array}{c}2 \text { or } \\
\text { only } \\
>65 y o\end{array}$ & $68 \%$ & 98.6 \\
\hline $\begin{array}{c}\text { 高リスク } \\
\text { High (35\%) }\end{array}$ & $\begin{array}{l}3 \text { or } \\
\text { more }\end{array}$ & $36 \%$ & 43.5 \\
\hline
\end{tabular}

図1 WM患者の予後予測モデル : International Prognostic Scoring System for WM (ISSWM) (Morel P, et al : Blood 113 : 4163-4170，2009より引用)

$5-\mathrm{yr}$ OS : 5 年生存率, mOS : $50 \%$ 生存期間 
深い経過観察が原則である. 第 7 回IWWMによ り提唱された治療開始基準を示す（表 2) ${ }^{8}$. 第 6 回IWWM会議においては, 国際的に統一した 治療効果判定基準 (Uniform Response Criteria for WM）が示された ${ }^{8)}$.

\section{2）未治療症候性WM患者に対する治療}

治療開始にあたり留意すべき点がある。第一 に，過粘稠度症候群を有する場合には，薬物療 法開始前に血漿交換を行う。行わない場合に は, 薬物療法開始後に粘膜出血, 脳出血, 眼底 出血, 昏睡, 心不全等を引き起こす危険性があ

\section{表 2 WM患者における治療開始規準 (第7回 IWWM)}

(Dimopoulos MA, et al : Blood 124 : 1404-1411，2014よ り引用)

- 臨床的適応

繰り返す発熱，盗汗，体重減少，倦怠感

一過粘稠度症候群

一症状があるか，長径 $\geqq 5 \mathrm{~cm}$ のリンパ節腫大

一症状のある肝腫大，または脾腫

一症状のある臓器腫大，または臓器 (組織) 浸潤

一WMによる末梢神経障害

・検査所見による適応

一症状のあるクリオグロブリン血症

一寒冷凝集素症による溶血性貧血

一免疫性溶血性貧血，または血小板減少症

一WMに関連する腎障害

一WMに関連するアミロイドーシス

一へモグロビン値 $\leqq 10 \mathrm{~g} / \mathrm{dl}$

一血小板数 $<10$ 万 $/ \mathrm{mm}^{3}$
る. 薬物療法前に血清IgMが 4,000 mg/dl以上の 場合，予防的な血漿交換の実施が推奨される. 第二に, 薬物療法後の血清IgM值の上昇 (IgM flare）である. 特に抗CD20抗体であるリツキシ マブ (rituximab：R）を投与する場合は， IgM flareに伴う過粘稠度症候群の増悪リスクが高い ため, R併用化学療法に際してIgM高值の場合に はR投与開始を遅らせる等の配慮が必要であ る. 第三に, IgM関連末梢神経障害を合併して いる患者には, 神経障害を悪化させる薬剤の使 用に注意する。再発時に自家造血幹細胞移植の 適応となる患者には, 造血幹細胞採取に影響を 与えるような薬剤，すなわち，シクロホスファ ミド以外のアルキル化薬やプリンアナログの使 用を控えるべきである。

第 8 回IWWMにおける初期治療の指針を示す (図 2) ${ }^{9)}$. IgM関連末梢神経障害のみで低腫瘍量 の場合には, R単剂あるいはRと化学療法の併用 が推奨される. 化学療法としては, アルキル化 薬, ベンダムスチン, プリンアナログ, プロテ アソーム阻害薬, サリドマイド等が使用され, デキサメタゾンを追加した３剤併用を選択する こともある。我が国では，サリドマイドとプロ テアソーム阻害薬であるボルテゾミブ, カル フィルゾミブは保険適応外である. 過粘稠度症 候群を認める場合や高腫瘍量の場合には, ベン ダムスチン $+\mathrm{R}$ (Benda-R) 療法あるいは, デキ

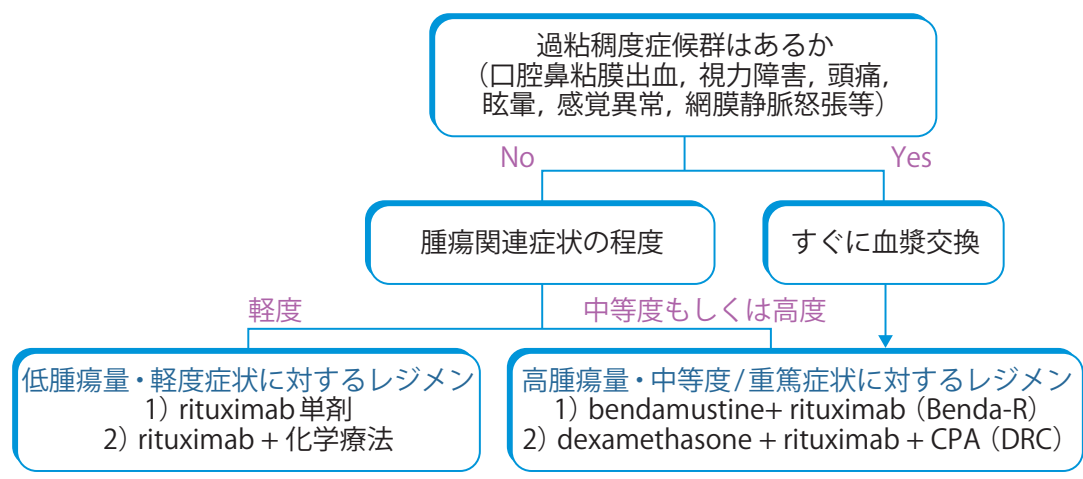

図2 未治療の症候性WMに対する推奨治療（第8回IWWM）

(Leblond V, et al : Blood 128：1321-1328, 2016より図示化) 
表3 WMに対する治療レジメンと臨床効果

(Leblond V, et al : Blood 128：1321-1328，2016より改変引用)

\begin{tabular}{|c|c|c|c|c|c|c|c|}
\hline レジメン & 症例数 & 未治療 & 前奏効割合 & $\geqq P R$ & $C R$ & TTP 中央值 & PFS 中央値 \\
\hline DRC & 72 例 & $100 \%$ & $83 \%$ & $74 \%$ & $7 \%$ & 35 月 & \\
\hline R-Fludarabine & 43 例 & $63 \%$ & $95 \%$ & $86 \%$ & $4 \%$ & 51 月 & \\
\hline \multirow{3}{*}{$\begin{array}{c}\text { R-Fludarabine/ } \\
\text { Cyclophosphamaide } \\
\text { (FCR) }\end{array}$} & 43 例 & $65 \%$ & $79 \%$ & $74 \%$ & $11 \%$ & NR & \\
\hline & 82 例 & $33 \%$ & $81 \%$ & $74 \%$ & $10 \%$ & & $79 \%$ at 3 年 \\
\hline & 40 例 & NT & $80 \%$ & $80 \%$ & $10 \%$ & NR & \\
\hline \multirow{2}{*}{$\begin{array}{l}\text { R-Bendamustine } \\
\text { (Benda-R) }\end{array}$} & 22 例 & $100 \%$ & $95 \%$ & NA & NA & 69.5 月 & \\
\hline & 71 例 & $100 \%$ & $80 \%$ & $75 \%$ & $7 \%$ & NR & \\
\hline \multirow{2}{*}{ R-Bortezomib } & 26 例 & $100 \%$ & $88 \%$ & $65 \%$ & $4 \%$ & NR & \\
\hline & 37 例 & NT & $81 \%$ & $51 \%$ & $5 \%$ & 16月 & 15.6月 \\
\hline \multirow{2}{*}{$\begin{array}{l}\text { R-Bortezomib /DEX } \\
\text { (BDR) }\end{array}$} & 23 例 & $100 \%$ & $96 \%$ & $83 \%$ & $13 \%$ & 66 月 & \\
\hline & 59 例 & $100 \%$ & $85 \%$ & $68 \%$ & $3 \%$ & & 42 月 \\
\hline R-Carfilzomib /DEX & 31 例 & $90 \%$ & $87 \%$ & $68 \%$ & $3 \%$ & $64 \%$ at 15 月 & \\
\hline R-Lenalidomide & 16 例 & $75 \%$ & $50 \%$ & $25 \%$ & $0 \%$ & 17 月 & \\
\hline Everolimus & 60 例 & NT & $73 \%$ & $50 \%$ & $0 \%$ & 25 月 & 21 月 \\
\hline Ibrutinib & 63 例 & NT & $90.5 \%$ & $73 \%$ & $0 \%$ & & $69 \%$ at 2 年 \\
\hline
\end{tabular}

TTP : 無増悪期間，PFS : 無増悪生存期間，NT : not tested，NA : not analyzed, PR : partial response,

CR : complete response, NR: not reported.

bortezomib, carfilzomib, ibrutinib, lenalidomide, everolimusは我が国では適応外

サメタゾン $+\mathrm{R}+$ サクロホスファミド $(\mathrm{DRC})$ 療 法が推奨されている. CHOP（シクロホスファ ミド+ビンクリスチン+ドキソルビシン＋プレ ドニン $\left.{ }^{\circledR}\right)+/$ R療法のランダム化比較試験で は， R追加による効果が示されている，前述の 留意点と臨床病態を踏まえて，これまでに臨床 試験において報告された主要なレジメンの臨床 効果を示す (表3 $)^{9}$. 初回治療が奏効した場合 のR維持療法は推奨されている. 欧米では, BTK 阻害薬であるイブルチニブが未治療例に対して も承認されている. 再発・再燃WM患者 63 名を 対象とした第II相治験において，73\%の奏効割 合（部分奏効以上）が示された ${ }^{10)}$. 興味深いこ とに, イブルチニブの効果は, MYD88変異を有 さない患者に比較してMYD88 L265P変異を有

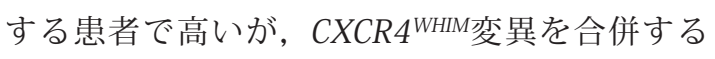
と効果が減弱することが報告されている，イブ ルチニブに対する耐性化には, CXCR $4^{\text {WHIM 変異 }}$ に加えて, BTK自体の変異が関与する場合もあ
る. 我が国では，WM患者への本剂の使用は承 認されていない.

\section{3）救援療法と新規薬骫による治療}

初回治療終了後 2 年以上経ってからの再発で あれば, 初回治療を再度実施（re-treatment）す ることにより効果を期待できる。早期再発ある いは初回治療中増悪の場合には, レジメンを変 更する。救援療法に対する感受性があり, 既治 療レジメン数が 2 以下の高リスクWM患者に対 しては, 自家造血幹細胞移植を併用した大量化 学療法を実施する選択肢もある。低毒性レジメ ンの効果が減弱した場合は, フルダラビン併用 療法も検討できるが, 自家造血幹細胞移植を考 慮する患者に対しては, 投与前に造血幹細胞採 取を済ませておく，米国においては，mTOR阻 害薬であるエベロリムス, 新規プロテアソーム 阻害薬であるイキサゾミブ，ヒストン脱アセチ ル化酵素阻害薬であるパノビノスタット, $\mathrm{Bcl} 2$ 
阻害薬であるvenetoclaxも臨床試験の範疇で投 与されている。

\section{おわりに}

WMは低悪性度B細胞性リンパ腫の1つで, IgM型M蛋白血症を認めた場合に鑑別すべき重 要な疾患である。多彩な症状で発症するため, さまざまな診療科医師が遭遇する可能性があ り, 内科医として疾患概念を理解しておく必要 がある. 近年の分子病態の解明が, 有効な分子 標的薬の開発につながることが期待される.
謝辞 本教育講演にあたりご指導ご協力いただきま した関口直宏博士 (独立行政法人国立病院機構災害医療 センター血液内科) と稲垣淳博士 (名古屋市立西部医療 センター血液・腫瘍内科）に深謝致します.

著者のCOI (conflicts of interest) 開示: 飯田真介 ; 講演 料 (小野薬品工業, セルジーン，武田薬品工業，ノバル ティスファーマ, ブリストル・マイヤーズスクイブ, ヤ ンセンファーマ)，研究費・助成金 (アッヴィ, MSD， 小野薬品工業，ギリアド・サイエンシズ，グラクソ・ス ミスクライン，サノフィ，ジェイファーマ，セルジー ン，第一三共，武田薬品工業，日本イーライリリー，バ イエル薬品，ノバルティスファーマ，ブリストル・マイ ヤーズスクイブ, ヤンセンファーマ), 寄附金 (アステ ラス製薬，小野薬品工業，協和発酵キリン，中外製薬， 帝人ファーマ，富山化学工業）

\section{文献}

1) Ghobriel IM : Are you sure this is Waldenström macroglobulinemia? Hematology Am Soc Hematol Educ Program $2012:$ 586-594, 2012.

2）関口直宏：原発性マクログロブリン血症. medicina $52: 2110-2113,2015$.

3) Kyle RAet al : Immunoglobulin M monoclonal gammopathy of undetermined significance and smoldering Waldenström macroglobulinemia. Clin Lymphoma Myeloma Leuk 13 : 184-186, 2013.

4) Treon SP, et al : MYD88 L265P somatic mutation in Waldenström's macroglobulinemia. N Engl J Med 367 : 826-833, 2012.

5) Hunter ZR, et al : The genomic landscape of Waldenström macroglobulinemia is characterized by highly recurring MYD88 and WHIM-like CXCR4 mutations, and small somatic deletions associated with B-cell lymphomagenesis. Blood 123 : 1637-1646, 2014.

6) Owen RG, et al : Clinicopathological definition of Waldenström's macroglobulinemia : consensus panel recommendations from the second international workshop on Waldenström's macroglobulinemia. Semin Oncol 30 : 110-115, 2003.

7) Morel P, et al : International Prognostic Scoring System for Waldenström macroglobulinemia. Blood 113 : 4163-4170, 2009.

8) Dimopoulos MA, et al : Treatment recommendations for patients with Waldenström macroglobulinemia (WM) and related disorders : IWWM-7 consensus. Blood 124: 1404-1411, 2014.

9) Leblond $\mathrm{V}$, et al : Treatment recommendations from the eighth International Workshop on Waldenström's macroglobulinemia. Blood 128 : 1321-1328, 2016.

10) Treon SP, et al : Ibrutinib in previously treated Waldenström's macroglobulinemia. N Engl J Med 372 : 14301440, 2015. 